14. Cyber Security Strategy, available at: https://www.mkm.ee/sites/default/files/cyber_security_strategy_20142017_public_version.pdf/ (rus).

15. The teachings of cybersemiotics «Cyber Coalition 2015», available at: https://www.melkon.Iv/news/2015/11/19/ucheniyakiberzashhitnikov-cyber-coalition-2015/ (rus).

16. Seljanin, Ja. V. (2017), The role of the Pentagon in cybersecurity USA, National security issues, Vol.3(42), pp.130-147 (rus).

17. In Tallinn to discuss European cyber-security, available at: https://www.tatar-inform.ru/news/2016/02/04/490207/ (rus).

18. The head of the Estonian foreign Ministry called on the EU and NATO to strengthen the cyber defence, available at: http:// baltnews.ee/policy/20160407/1014657973.htm/ (rus).

19. Cyber security strategy of Latvia 2014-2018, available at: https://www.enisa.europa.eu/topics/national-cyber-security-strategies/ ncss-map/lv-ncss (eng).

20. Zemessardzes Kiberaizsardzī bas vienī ba, available at: http://www.zs.mil.Iv/Zemessardzes\%20vienibas/ kiberaizsardzibas vieniba.aspx (lat).

21. Nacionālo bruņoto spēku kiberaizsadzī bas vienī bas (kav) koncepcija, available at: http://www.mod.gov.lv/ /media/AM/ Par_aizsardzibas_nozari/Plani,\%20koncepcijas/\%20cyberzs_April_2013.ashx (lat).

22. Nacionālās drošī bas koncepcija (informatī vā dal a), available at: https://likumi.lv/ta/id/278107-par-nacionalas-drosibaskoncepcijas-apstiprinasanu (lat).

() Гапеєва Ольга

Надійшла до редакції 13.11.2017

УДК [327.7 (477): 430] "1918/1923)

DOI: $10.21847 / 1728-9343.2017 .6(152) .122285$

\title{
ЗАБОЛОТНЮК ВОЛОДИМИР,
}

здобувач, провідний науковий співробітник

Науково-дослідного відділу (механізованих і танкових військ),

Науковий центр Національної академї сухопутних військ, м. Львів

\section{УКРАЇНСЬКІ ДИПЛОМАТИЧНІ ІНСТИТУЦІї В НІМЕЧЧИНІ В 1918-1923 pp.}

У статті розглядається становлення та діяльність у Німеччині українських посольств та консульських установ у 1918-1923 рр. У Берліні були представлені дипломатичні установи Української Народної Республіки доби Центральної Ради (посол Олександр Севрюк), Української Держави (барон Федір Штейнґель), Української Народної Республіки доби Директорії УНР (Микола Порш, Роман Смаль-Стоцький). Своє посольство утворила в Берліні й ЗахідноУкраїнська Народна Республіка (Євген Левицький, Ярослав Біберович). Але 3 огляду на можливу негативну реакцію країн Антанти посольство ЗУНР не розвинуло ширшої діяльності. Україна мала свої консульські установи в Берліні та Мюнхені. У статті згадується також про діяльність української консульської установи в Данцигу (Гданську), який був тісно пов'язаний з Німеччиною. Українські дипломатичні структури в Німеччині були офіційно визнані німецькою владою й свої головні зусилля спрямували на пошуки зовнішньої підтримки України в боротьбі з ворогами їі незалежності. Дипломати разом із військово-санітарними місіями здійснювали опіку над полоненими українцями - вояками колишньої російської армії, які утримувалися в таборах Німеччини, також піклувалися про тих українців, які залишилися в еміграції й працювали чи навчалися в цій країні.

Ключові слова: дипломатія; посольства; консульські установи; військова еміграція; Ярослав Біберович; Євген Левицький; Микола Порш; Олександр Севрюк; Роман Смаль-Стоцький; Федір Штейнгель.

Постановка та актуальність проблеми. Українські національні уряди в добу революції за кордоном створювали дипломатичні установи та місії. Їхня діяльність мала серйозний вплив на міжнародний аспект самостійницьких прагнень українських урядів. Українська дипломатія новітнього характеру відзначає 100-літній ювілей.
На окремий розгляд заслуговує діяльність українських дипломатів у 1918-1923 рр. у Німеччині, яка офріційно визнала українську державність. Відтак вивчення становлення та діяльності українських дипломатичних установ у Німеччині сприятиме глибшому розумінню міжнародного контексту українських визвольних змагань та обставин становлення української військової еміграції. 
Ступінь дослідження проблеми. Формування та діяльність українських дипломатичних установ у Німеччині привертає увагу дослідників історії міжнародних відносин України. В. Даниленко і Н. Кривець розглядали це питання у вступі до тематичного збірника документів [1], головні події інституційної історії української дипломатії розглянула І. Матяш [2]. Проблеми визнання України державами Заходу та встановлення дипломатичних відносин у 1917-1919 рр. висвітлив у своїй статті О. Машевський [3]. Діяльність дипломатії УНР у боротьбі за незалежну українську державу досліджував В. Головченко [4]. І. Дацків проаналізував міжнародний та економічний контекст підписання військової конвенції під час мирних переговорів у Бресті [5-6]. Окремі аспекти діяльності посольств у Німеччині згадуються у статті П. Гай-Нижника [7], монографріях С. Наріжного [8] та О. Павлишина [9]. В. Піскун ґрунтовно дослідила політичне життя української еміграції у 1920-х рр. [10]. М. Швагуляк висвітлив розвиток суспільно-політичної ситуації в Німеччині, у т. ч. й у зазначений період [11].

Життєпису та діяльності українських дипломатів у Німеччині присвячені дослідження П. Брицького [1213], В. Верстюка, Т. Осташко [14], П. Гай-Нижника [1516], О. Добржанського [17], І. Кедрина-Рудницького [18], Н. Кривець [19] та І. Матяш [20-21]. Утім, узагальнювальної праці, яка б розкрила характер та обставини діяльності українських дипломатичних інституцій в Німеччині, досі не опубліковано.

Мета статті - висвітлити формування та діяльність українських дипломатичних представництв у Німеччині в 1918-1923 рр., спрямовану на міжнародне визнання української державності, допомогу військовополоненим українцям, підтримку української військової еміграції.

Головні джерела для дослідження: архівний документ [22], ряд збірників опублікованих документів [2332], спогади Є. Онацького [33], записник О. Жуковського [34], мемуари колишніх студентів політехнічного Інституту в Данцигу (Гданську) [35], публікації в українських періодичних виданнях, які друкувалися в еміграції [3646]. Водночас автор уважає за необхідне опрацювання ряду закордонних досліджень, дотичних до досліджуваної проблеми, зокрема праць [50-55] та ін. Аналіз цих праць, на думку автора, є окремим питанням, яке треба розглянути в рамках спеціального дослідження.

Виклад основного матеріалу. Важливим напрямком діяльності української влади періоду національно-визвольних змагань були заходи, спрямовані на міжнародне визнання української державності й пошуків зовнішньої підтримки в боротьбі з ворогами української незалежності. На передній лінії таких зусиль були посольства та дипломатичні місії України в державах світу. Щодо Німеччини, то тут українським представництвам ставилося в обов'язок опікування полоненими українцями - вояками колишньої російської армії, які утримувалися в таборах цієї держави.

Українські національні уряди відкривали дипломатичні представництва в Берліні, офріційно визнані німецькою владою. Українська Центральна Рада направила своїм послом до Німеччини Олександра Севрюка, який прибув до цієї країни напередодні гетьманського перевороту в Києві - у квітні 1918 р. [3, с. 85]. На той час О. Севрюк уже мав важливі здобутки на дипломатичній ниві. Він, будучи керівником української делегації, виявив неабиякі дипломатичні здібності на переговорах у Бресті. У січні-лютому 1918 р. О. Севрюк, перебуваючи на чолі делегації, досягнув визнання Української Народної Республіки (далі - УНР) як самостійної і суверенної держави країнами Четвертного Союзу.
26 січня 1918 р. О. Севрюк першим з українських дипломатів підписав Берестейську мирну угоду. Крім того, він домігся від представників Австро-Угорщини підписання таємної угоди про створення зі Східної Галичини та Буковини окремого коронного краю. 4 березня 1918 р. між представниками Четвертного Союзу та УНР був підписаний окремий договір щодо Холмщини. Утім, недовго перебуваючи на посаді посла УНР у Німеччині, він припустився помилок, які, у результаті, привели до відмови Австро-Угорщини від узятих на себе зобов'язань стосовно утворення окремого українського коронного краю [14, с. 158].

Уряд Української Держави в час правління гетьмана Павла Скоропадського представляв у Берліні посол барон Федір Штейнгель $[48,49]$. Рішення про заснування в Берліні посольства I розряду Рада міністрів ухвалила 21 червня 1918 р. [4, с. 67]. Про призначення Ф. Штейнгеля послом П. Скоропадський повідомив у червні 1918 р. імператора Німеччини Вільгельма II, запевнивши, що він виявить себе достойним довіри Його Величності [28, с. 63]. Ф. Штейнгель прибув до Берліна 1 липня 1918 р., а вірчі грамоти з рук кайзера Вільгельма II отримав тільки 9 листопада того ж року [15, с. 106]. Але український посол розпочав свою працю задовго до отримання вірчих грамот. Найперше він відвідав міністра закордонних справ Німеччини фон Кюльмана [15, с. 108]. Новоприбулого українського посла 5 липня 1918 р. привітали офріцери й рядові полонені-українці, яких утримували в таборі в Ганновер-Мюндені [28, с. 63].

За порівняно невеликий час перебування на чолі посольства Ф. Штейнгель влаштував декілька офіційних прийомів за участю акредитованого в Німеччині дипломатичного корпусу та представників німецьких політичних, військових та фрінансових середовищ. Посол зумів установити приязні стосунки з послами нейтральних держав - Нідерландів та Іспанії, сприяв визнанню Української Держави Грузією та Фінляндією. Зокрема, 25 липня 1918 р. в українському посольстві приймали голову грузинської делегації в Німеччині князя Авалова та члена делегації $€$. Гегечкорі, які підтвердили юридичну силу раніше підписаних українсько-грузинських угод. Грузинські делегати зі свого боку звернулися до українського посла з проханням здійснити заходи задля визнання Україною Грузинської Демократичної Республіки як самостійної держави й водночас заявили, що їхня країна готова до визнання Української Держави [7, с. 129].

Ф. Штейнгель почав займатися також долею військовополонених українців та біженців, які на той час перебували в Німеччині [19, с. 333]. Припинення діяльності О. Штейнгеля співпало із завершенням світової війни. 9 листопада 1918 р. Німеччину було проголошено республікою, а уряд очолив соціал-демократ Ф. Еберт, який зайняв посаду канцлера. 11 листопада 1918 р. у Комп'єнському лісі Німеччина та держави-переможниці (країни Антанти) підписали угоду про перемир'я [11, с. 564]. Фактична капітуляція Німеччини у світовій війні та поразка режиму П. Скоропадського змусили Ф. Штейнгеля повернутися в Україну [19, с. 333-334].

Після повалення гетьманської влади, Рада Народних Міністрів 2 січня 1919 р. призначила послом у Німеччину відомого публіциста, діяча Української соціал-демократичної робітничої партії Миколу Порша [16, с. 136]. Але той через проблеми з комунікацією прибув до німецької столиці 10 лютого 1919 р. й наступного дня офріційно перейняв справи українського посольства [16, c. 137]. Проголошення злуки УНР і ЗУНР сприяло утворенню об'єднаного українського посольства на чолі 3 
М. Поршем. Буковинець Роман Смаль-Стоцький, який до того був представником ЗУНР у Німеччині, став його радником [13, с. 318].

Закінчення війни активізувало суспільно-політичну ситуацію в Німеччині. У 1919 році ця країна пережила друге революційне піднесення. У серпні 1919 р. Національні Збори, які засідали у м. Веймар, ухвалили конституцію Німецької Республіки, що увійшла в історію цієї країни як Веймарська республіка. Конституція поєднувала парламентську форму правління з президентською владою. Найвищий законодавчий орган Райхстаг обирався на чотири роки шляхом загальних і рівних виборів. Революційні перетворення сформували нову партійно-політичну систему, основою якої стала т. зв. Веймарська коаліція: Соціал-демократична партія $\mathrm{Hi}-$ меччини, партія Центру і ліберальна лівиця. Остання перетворилася згодом на Німецьку демократичну партію. Для Німеччини особливо важкими були умови Версальського миру, підписаного у Франції з державамипереможцями, за яким Німеччина втратила свої території на користь Бельгії, Данії, Польщі, Франції та Чехословаччини; віддала 90 \% морського торговельного фрлоту, збройні сили були обмежені в чисельному та технічному вимірі. Визнана винуватцем війни, Німеччина була змушена виплачувати іншим державам величезні репарації [11, с. 564]

У таких умовах головною метою посольства УНР було проведення зовнішньополітичної діяльності з метою міжнародної підтримки української незалежності. Коли більшість держав світу юридично не визнавали української державності, посольство в Німеччині, як й в інших країнах, проводило інфрормаційно-пропагандистську роботу, метою якої було поширення об'єктивної інформації про ситуацію в Україні, політичну орієнтацію керівництва держави, національно-культурний потенціал української нації. Діяльність у цьому напрямку була необхідна з огляду на те, що про Україну мало знали в політичних колах зарубіжжя та серед громадськості. Поряд із цим необхідно було поборювати шкідливі й ворожі для України пропагандистські заходи з боку Польщі, російського емігрантського руху та більшовицької Росії, які претендували на українські землі [1, с. 17].

М. Порш у своєму звіті до міністра закордонних справ УНР Володимира Темницького сфрормулював пріоритети діяльності посольства у Німеччині таким чином: здобути якнайбільший вплив на різні політичні середовища, промисловців, військових та пресу Німеччини; впливати на корисні для України рішення німецького уряду; матеріально підтримувати видання німецькомовного журналу "Україна", який видавався Німецькоукраїнським товариством та був присвячений українським справам; налагодити конструктивну співпрацю 3 фрінансовою комісією німецького уряду; співпрацювати з німецькими колоністами в Україні, які мають у Німеччині корисні зв'язки та впливи; узгодити спільні дії з місцевими євреями стосовно Польщі; відновити стосунки з військовими сфрерами Німеччини, які послабилися після закінчення світової війни; активізувати діяльність інформаційного відділу посольства [23, с. 718-720].

Посольство в Берліні було розташоване у приміщенні за адресою Кронпрінценуфер (Kronprinzenufer), буд. 10 [29, с. 47]. Структура посольства не мала сталого характеру, українська дипломатична установа поділялася на п'ять відділів: дипломатичний, господарський, канцелярія, консульський та інфрормаційний [28, c. 277-278].

Наприкінці травня 1920 р. посольство УНР у Берліні оголосило про реєстрацію всіх фахових сил з України, які на той час перебували на території Німеччини. До посольства з метою реєстрації повинні були зголошуватися: 1) технічні фахівці (інженери, техніки, залізничники); 2) державні урядовці колишньої Російської держави а також державні урядовці УНР, які у той час перебували у Німеччині; 3) усі офріцери та підофіцери [45, с. 3].

Поряд із діяльністю в німецькій столиці посольства, яке виконувало передусім політичні функції, українська влада відкрила консульські установи. Відомо, що консульський відділ посольства УНР у Берліні очолював Г. Петренко. Працівниками були старший урядовець В. Пожидаєв та М. Слива, який працював на умовах вільного найму. Українське посольство разом із консульством налагодило виготовлення та видачу паспортів українським емігрантам. Відділ у 1920 р. видав i продовжив 6180 українських паспортів, 1145 посвідчень на перебування в Німеччині та т. зв. перехідних свідоцтв, видав 1369 віз [1, с. 37]. Проте незабаром Г. Петренко потрапив під вплив більшовицької агентури та перейшов на роботу в радянське представництво в Берліні [10, c. $286-287]$

Посол М. Порш звертався до українського посольства в Італії, щоб воно вплинуло на італійський уряд у справі видачі віз українським громадянам у Німеччині [33, с. 42]. Улітку 1921 р. видача паспортів перейшла на платну основу. Паспортний відділ українського посольства вимагав від українських громадян сплату по 200 марок за вироблення паспорта та по 100 марок за продовження візи. Із цього приводу український емігрантський часопис зауважив: "Цю подать мусять платити не лише заможніші люде та ріжні спекулянти 3 українськими паперами, а й ті нещасні полонені, які остались на роботі у Німеччині, та українське студентство" [44, с. 71$]$.

Окремо треба відзначити створення та діяльність консульської установи у Мюнхені - центрі Баварії. Гетьман П. Скоропадський своїм указом 15 листопада 1918 р. призначив на посаду консула Української Держави в Мюнхені віце-директора загального департаменту МЗС Василя Оренчука [21, с. 356]. Штат консульства складався $з$ посади самого консула, секретаря й канцелярського працівника. Консульство розташувалося й розпочало роботу з 1 січня 1919 р. у приміщенні будинку на вул. Люціле-Грандштрассе, а згодом переїхало в будинок на вул. Айнміллерштрассе, 5/II [21, с. 356]. Василь Оренчук багато зробив для налагодження політичних та економічних стосунків України з Німеччиною [20, с. 58-59]. У першій половині 1919 р. консульство УНР у Мюнхені зіткнулося з проблемою видачі паспортів вихідцям з Галичини, тому що не мало у своєму розпорядженні відповідних законодавчих актів ЗУНР, які замінили колишні австрійські закони [28, с. 170-171].

Уряд УНР відкрив також консульську установу у вільному місті Данцигу. Консулом призначили полковника Армії УНР Клима Павлюка, який разом зі своєю дружиною доклав зусиль для активізації української громади [35, с. 52]. 7 травня 1921 р. Симон Петлюра звернувся до міністра закордонних справ УНР Андрія Ніковського з проханням дати розпорядження консулу в Данцигу К. Павлюку, щоб той "пильно стежив за відправкою з Німеччини амуніції до Сов. Росії,... і своєчасно присилав повідомлення" [25, с. 495].

До Берліна не раз приїздили українські високопосадовці, які в той чи інший спосіб вирішували свої справи в посольстві. У німецький столиці перебували, зокрема, Володимир Винниченко та Борис Мартос [27, c. 60, 120-121]. У Берліні провадив ширшу діяльність фінансовий агент Міністерства фонансів УНР Григорій Супрун [33, с. 43]. Деякий час перебували в Берліні пред- 
ставник УНР в Лондоні Арнольд Марголін та міністр УНР Христофор Барановський [43, с. 301]. Улітку 1920 р. у зв'язку з приїздом Б. Мартоса у Берліні відбулися наради членів Української соціал-демократичної робітничої партії [41, с. 80].

У німецьку столицю часто навідувалися українські посли, які представляли Україну в інших державах. Чи не найбільше в німецькій столиці бував барон Микола Василько. У січні 1920 р. часопис "Воля" інформував, що у зв'язку з подіями в Україні до Берліна з'їхалася велика кількість послів УНР за кордоном: "Найчастіше їх можна побачити на Клеіст-Штрассе 25 в помешканню фрінансового агента УНР п. Супруна" [37, с. 87].

Серйозною проблемою для ефективної діяльності українського посольства в Німеччині стали неоднозначні оцінки діяльності посла Миколи Порша. У перше півріччя своєї праці на посольській посаді він уважався одним із найбільш впливових персон українського дипломатичного корпусу. Зокрема, на конференції послів і шефів дипломатичних місій УНР, яка відбувалася в Карлсбаді 6-14 серпня 1919 р. М. Порш визначив порядок денний нарад, який схвалили всі присутні тут дипломати, і був серед найбільш активних доповідачів та дискутантів [31, р. 245, 247]. Зокрема, М. Порш зробив критичний аналіз діяльності та фаховості персоналу українських посольств. Висловив своє бачення напрямків діяльності та функцій посольств, наполягав на оптимізації їх кількісного складу [31, р. 274, 276-278].

У Записній книжці колишнього військового міністра УНР Олександра Жуковського йдеться про його розмову 2 липня 1919 р. із заступником голови фінансової місії УНР у Німеччині О. Скнаром з приводу серйозного незадоволення німецької влади діяльністю М. Порша [34, с. 78-79]. 3 іншого боку, в українських колах за кордоном наприкінці 1919 р. - на початку 1920 рр. почали обговорювати критичне ставлення до М. Порша уряду УНР. Його викликали для розмови до осідку уряду, але він покликався на свою хворобу й не з'являвся до керівництва республіки [37, с. 87].

Відомо, що 14 листопада 1919 р. призначення на посаду посла УНР у Берліні отримав Микола Василько. Утім, 24 листопада того ж року він у листі міністру зовнішніх справ УНР, відмовився від цієї посади, звертаючи увагу на негативні наслідки такого призначення для української справи. М. Василько відзначив, що антантські кола, знаючи про його добрі стосунки з колишніми міністрами Австрії та Німеччини, негативно б оцінили таке призначення [31, р. 424-426]. "Моє призначення до Берліна викличе в Антанти підозру, що Україна знову приділяє велику вагу на стосунки з Німеччиною, якщо висилає туди одного з найздібніших своїх дипломатів. Вона собі тоді пригадає - не тільки за допомогою пана Галіпа, але й також наших українських дипломатів, які мають знайомства в колах Антанти - що Василько завжди був германофрілом. I через те, що Петлюра висилає до Берліна германофіла Василька, вона зробить ті висновки, що він старається знову впровадити нову орієнтацію в заграничній політиці" [31, р. 426].

О. Добржанський стверджує, що хоча уряд УНР був незадоволений діяльністю М. Порша, але зволікав 3 офріційним відкликанням його з посади посла. Утім, хоча призначення М. Василька до німецької столиці й не відбулося, проте він за завданням уряду УНР й особисто С. Петлюри брав активну діяльність у справах посольства й навіть здійснював неофіційне керівництво ним. Відомо, що Василько перебував у Берліні у грудні 1919 р., січні 1920 р. та з 1 березня до червня 1920 р. $[17$, c. $187-188]$.

Віденська газета "Воля" з цього приводу відзначи- ла: "Нас повідомляють з Берліна, що п. Матюшенко зрікся прийняти справи посольства від кол. укр. посла п. Порша. Так само і барон Василько під впливом Грушевського повертає з Берліну до Швейцарії. Таким чином, у Берліні знов лишається п. Порш. Іронічна заява німців, що Порш у Берліні сидить міцніше, ніж Петлюра на Україні" - видно, і справді недалека від істини" [38, с. 332]. Про проблеми українського посла М. Порша доповідали своєму керівництву й польські спецслужби [32, р. 104].

М. Порша відкликали з посади посла на зламі 19201921 рр., й уповноваженим уряду УНР в Берліні залишився Р. Смаль-Стоцький, який виконував свої обов'язки аж до ліквідації посольства 1923 р. Він мав статус "повіреного у справах УНР у Німеччині" [43, с. 301]. У цей час М. Василько надалі здійснював політичний нагляд за посольством й мав право приймати важливі рішення. Цю обставину засвідчує такий епізод. Наприкінці 1920 р. Р. Смаль-Стоцький звернувся з листом до П. Скоропадського, який мешкав у Німеччині, з проханням про його підтримку в справі прийняття України до Ліги Націй. Після оприлюднення цього листа, на нього з обуренням відреагував М. Василько. Він послався на наказ Міністерства закордонних справ УНР від 24 серпня 1920 р. № 44/13, підкресливши, що згідно з цим наказом "діяльність нашого Посольства у Берліні, керуючим справами цього являєтесь Ви, підлягаєте моєму доглядові, - цим категорично пропоную Вам, згідно зазначеного вище наказу, ніякої службової кореспонденції всякого змісту не надсилати надалі без мого ії одобрення. Уповноважений Міністер У.Н.Р. Посол Василько, в. р." [42, с. 155-156].

Працівники посольства в різний спосіб намагалися гідно представити свою державу у Берліні. Улаштовували сходини, прийняття, спільні українсько-німецькі наради [8, с. 98]. Поряд із цим українське посольство, виконуючи свою роботу, не раз зверталося до німецьких установ з умотивованими претензіями й вимогами. Зокрема, у листопаді 1920 р. посольство вислало дипломатичну ноту до Міністерства закордонних справ Німеччини в справі полегшення в'їзду до Німеччини українських громадян з території Австрії та Чехо-Словаччини. Німецькі консулати у Відні та Празі не визнають згідно з розпорядженням німецького МЗС дипломатичних, кур'єрських та громадянських паспортів. Для вирішення цього питання українські дипломати попрохали від німецької влади відповідних інструкцій своїм консулатам у Відні та Празі [40, с. 409]. Повагу до посольства УНР підтвердив і фракт запрошення Р. Смаль-Стоцького 12 січня 1921 р. на раут Міністра закордонних справ Німеччини д-р Сіменса, на якому був увесь акредитований у Берліні дипломатичний корпус [44, с. 301].

3 іншого боку, на посольство покладалися завдання з'ясування зовнішньополітичних планів німецького уряду. 3 лютого 1921 р. С. Петлюра в листі до посла УНР розглядав імовірність інтервенції західних держав в Україну. Керівник Директорії припускав також і вірогідність більшовицького наступу, тому ставив дипломатові відповідні завдання: "Нам було б дуже важливо знати наміри німецького уряду на випадок більшовицької перемоги в наступі, і було б бажано, пане После, дістати від вас повнішу і точнішу інформацію в цій справі. Я маю відомості, що певні німецькі угруповання мають на думці створити корпус для румунської кампанії на Україні; з цим планом було б зв'язане відновлення влади Скоропадських. Я хотів би, пане После, що ви звернули увагу відповідних кіл у Німеччині на те, що здійснення такого пляну зустріне непереборні перепони. Не варто говорити про ілюзії Гетьмана, бо мала кількість 
його прихильників і німці були б знищені самими лише селянами і то за дуже короткий час" [25, с. 490].

Недруги України з метою дискредитації їі самостійності широко вели антиукраїнську пропаганду, використовуючи інформацію про погроми євреїв. Щоб паралізувати шкідливі наслідки цієї пропаганди, посольство замовило для розповсюдження брошуру єврейського діяча, колишнього члена Центральної Ради Соломона Гольдельмана німецькою мовою і подало спеціальну ноту до референта з єврейських справ МЗС Німеччини [43, с. 301]. Німецька влада у червні 1921 р. легалізувала берлінську фрілію Українського Червоного Хреста [44, с. 71].

Українські дипломатичні представництва наполегливо шукали порозуміння з німецькими промисловими колами. 25 січня 1921 р. Німецько-українське товариство організувало в берлінському готелі "Брістоль" прийом для представників банків, торгівлі та промисловості, на який запросили весь персонал посольства членів української колонії на чолі з А. Марголіним та міністром УНР X. Барановським. Серед німецьких промисловців, які були на прийомі, виникла думка про створення спеціальної економічної наради з представників німецьких промислових, торговельних та фінансових кіл, представників посольства УНР, українських кооперативних установ та промисловості й також провідних українських учених-економістів [43, с. 301]. 25 червня 1921 р. відбулося засідання Німецько-української торговельної спілки в Мюнхені [44, с. 71]. Це зібрання, за участю близько 500 берлінських і мюнхенських державних установ, відбулося насамперед завдяки наполегливим зусиллям консула В. Оренчука [20, с. 58].

Посольство вирішувало нагальні зовнішньополітичні питання не тільки в стосунках із країною перебування. Працівники українського посольства намагалися утримувати дипломатичні контакти з іншими посольствами, акредитованими у столиці Німеччини. У листопаді 1920 р. повірений у справах УНР у Німеччині Р. СмальСтоцький, у зв'язку з подіями на врангелівському фронті, відвідав бельгійського посла, радника французького посольства графра Сент-Кентена, посла Італії Де-Мартіно і шефа військової британської місії генерала Манкольма [40, с. 410].

Посольство надавало велике значення тій ролі, яку могли відіграти в українському державотворенні і міжнародних відносинах України далекосхідні колонії "Зелений Клин" та Маньчжурія. Тому розпочало в тому напрямку в Берліні відповідну дипломатичну акцію. Посол звернувся до посла Китаю в Німеччині з нотою, у якій підкреслив, що інтереси Китаю до територій колишньої Росії, подібно як і інтереси Японії, співпадають з інтересами всіх нових національних держав, які постали на території колишньої російської імперії. А особливий інтерес далекосхідні території становлять для УНР. Звернувши увагу на лист Української крайової ради в Маньчжурії, посольство попрохало китайських дипломатів ужити заходів перед їхнім урядом задля того, щоб українські крайові органи в Маньчжурії уважалися урядовими; щоб ці національні органи визнав Китай, узяв їх під свою охорону й надав їм право на самовизначення. Українські дипломати домагалися також, щоб китайський уряд фрінансово підтримав українські національні культурні інституції: школи, часописи тощо [40, с. 409-410].

29 січня 1921 р. увесь дипломатичний персонал українського посольства запросили на раут до нового посла Японії в Берліні І. Гіокі, де був увесь дипломатичний корпус, акредитований у Німеччині. Українське посольство на рауті представили Р. Смаль-Стоцький та секретар В. Хотько [43, с. 301]. Наприкінці січня 1921 р. посол Латвії д-р Войт організував для українських дипломатів урочистий вечір, на якому були присутні Р. Смаль-Стоцький і секретарі посольства В. Левицький та В. Хотько [43, с. 301].

Важливу роботу в посольстві УНР у Німеччині відігравав інформаційний відділ, створений на початку березня 1919 р. Керівником цього відділу був перший секретар посольства Володимир Левицький. Відділ спрямував свою діяльність на інформування німецької преси та широких кіл громадськості щодо українського питання та накопичення інформації для українського уряду [1, с. 17]. Питання актуальності розгортання при українських дипломатичних представництвах інформаційних відділів українські дипломати обговорили на засіданнях 11 серпня 1919 р. в Карлсбаді [31, р. 300305]. Інформаційний відділ посольства, або, як його називали, пресове бюро, видавав бюлетені, інформаційні брошури, постачав книги в табори для військовополонених, дбав про переклади німецькою мовою української літератури [8, с. 98]. Улітку 1921 р. інфрормаційний відділ надрукував книжечку про українців німецькою мовою: "Die Ukrainer. Vortrag von. Dr. Konrad Guenther Professor an der Universität Freiburg" [44, c. 71]. Посольство, окрім політичної діяльності, здійснювало важливу культурну функцію - організовувало зібрання української еміграції, лекції та диспути на теми політичного й економічного характеру [8, с. 98].

Необхідно відзначити, що не всі працівники посольства виявилися патріотами України. Улітку 1919 р. віденський часопис "Воля" проінформував українську еміграцію, що працівник дипломатичної установи УНР у Берліні Шостаков залишив роботу в посольстві й подався на службу до Денікіна. Окремі члени посольства та російська колонія в Берліні проводжали генерала на залізничному вокзалі та бажали йому успіхів на новій службі. Редакція часопису відзначила, що ця вістка видається їй не зовсім правдоподібною та очікувала спростування з Берліна [36, с. 89].

Працівники посольства пильно стежили за провокаційними діями в Німеччині з боку більшовицьких спецслужб. 10 вересня 1920 р. Р. Смаль-Стоцький повідомив контррозвідку Генштабу Армії УНР про те, що сотник Озоль, який служив у Берліні при інспекторі авіаційного фрлоту сотнику Кривенку, насправді був членом таємної більшовицької військової місії в Німеччині. Удалося встановити, що Озоль передав більшовицькій місії секретну інформацію щодо структури армії УНР. Р. Смаль-Стоцький перестеріг військові установи й прохав передати Озоля в разі повернення військово-польовому судові [13, с. 318-319].

Посольство УНР проводило значну роботу в напрямку репатріації військовополонених українців. Ще під час переговорів у Бресті член української делегації, тоді генеральний секретар з військових справ М. Порш, розповів дипломатам Центральних держав про складне становище УНР в умовах більшовицької агресії. Він спеціально попрохав Німеччину та Австрію військової допомоги, організувавши українські полки із числа полонених українців російської армії, яких утримували в цих країнах. Завдяки заходам Союзу визволення України в 1917 р. полонені українці були сконцентровані в таборах Фрайштадт, Зальцведель, Раштат, Вецляр та iн. [5, c. 105].

У березні 1918 р. у Берліні розпочала свою роботу Українська військово-санітарна місія (голова - Андрій Журавель, пізніше - сотник Микола Трезвінський). Українському урядові йшлося про те, щоб із полонених 6000 вояків у Німеччині та 4000 вояків в Австрії органі- 
зувати у військові частини та доповнити ними збройні сили УНР. За правління Директорії Військово-санітарну місію перейменували в Місію для справ полонених українців у Німеччині (голова - д-р Кость Воєвідка). Робота місії здійснювалася в координації з українським посольством у Німеччині та Місією українського Червоного Хреста (Петро Холодний), яка займалася придбанням ліків, медичного устаткування, білизни, одягу та постільних комплектів для свого війська $[47$, с. 21 31]. Представники посольства були присутні на відкритті пам'ятника померлим українцям у м. Вецляр 16 серпня 1919 р. [36, с. 234].

24 травня 1921 р. Р. Смаль-Стоцький звернувся до Міністерства закордонних справ УНР, яке тоді мало осідок у польському місті Тарнові: "Старшини Армії УНР звертались з запитаннями, чи не можна б їх відправити до Армії УНР, але рівночасно прибуває раз у раз усе більше старшин з Польщі, які тікають 3 концентраційних таборів і за всяку ціну хотять залишитися в Німеччині. Названі вище старшини за допомогою посольства УНР у Німеччині вже позаписувались до німецьких вищих шкіл і тепер ледве чи схотять повернутись до Армії, поки вона зістається інтернованою. Загалом треба сказати, що ті українські військові елементи, які зараз перебувають на теренах Німеччини, можуть бути використані лише в умовах війни, а поки лишається в силі існуючий стан речей, з Німеччини згодяться виїхати лише елементи гірші" [28, с. 406-407]. У той час обставини перебування українських емігрантів були ускладнені. Зокрема, уряд Баварії ускладнив дозвільні процедури перебування іноземців на її території [10, с. 37].

Дипломати опікувалися українськими студентами, серед яких було чимало колишніх вояків збройних сил України. Посольство допомагало студентам організаційно та матеріально: засновувало іменні стипендії, сприяло організації курсів українознавства [8, с. 98] Восени 1920 р. посольство подарувало через Міністерство закордонних справ Німеччини для слов'янських семінарів університетів Берліна, Лейпцига та Мюнхена комплекти книжок, складених з екземплярів усіх наукових та художніх видань, які надрукували українські видавництва за кордоном [40, с. 410].

Знаючи про важке матеріальне положення українського студентства за кордоном, посольство розгорнуло широку акцію задля здобуття коштів на допомогу студентам. Із цього приводу Р. Смаль-Стоцький звернувся до українських громадян, які перебували в Німеччині із закликом жертвувати кошти на допомогу молоді. Окрім того, посольство підготувало спеціальний меморіал про нужденне життя українських студентів та передало його берлінському комітетові Американського союзу християнської молоді. Копії цього меморіалу посольство передало до українського посольства у Відні та в українські дипломатичні місії в Берні, Варшаві, Парижі та Празі, попрохавши ці українські інституції, зі свого боку, звертатися до місцевих комітетів згаданого Християнського союзу [43, с. 300].

Окрім дипломатичних представництв Наддніпрянської України, дипломатичні стосунки з Німеччиною наладнала й Західно-Українська Народна Республіка. У листопаді 1918 р. міністр закордонних справ ЗУНР Василь Панейко призначив послом до Берліна Миколу Василька, а його заступником - Романа Смаль-Стоцького. Від червня 1920 р. до вересня 1921 р. обов'язки посла ЗУНР виконував Євген Левицький. На відміну від Посольства УНР, Євген Левицький не розгортав широкої діяльності, хоч на утримання цієї інституції ЗУНР виділялися значні кошти. Він мотивував свою обережну позицію прагненням не дратувати країни Антанти ак- тивною співпрацею з Німеччиною [24, с. 468-470]. Відтак послом у Німеччині Колегія уповноважених диктатора призначила Ярослава Біберовича, який перед тим представляв ЗУНР в Угорщині. Останній обіймав посаду посла ЗУНР у Берліні до весни 1923 р. [9, с. 309].

Функціонування посольства та здійснення ним різного роду зовнішньополітичних та міжнародних акцій потребувало відповідних коштів. 15 травня 1918 р. Українська Держава уклала з Центральними державами фінансову угоду, згідно з якою Україна надавала Німеччині та Австро-Угорщині позику в сумі 400 млн карбованців, яка в перерахунку на міцні валюти цих країн була розміщена на рахунках у державних банках Берліна, Відня та Будапешта.

Україна, за умовами українсько-німецько-австрійської угоди, не мала права протягом року розпоряджатися належними сумами і користуватися ними поза німецьким та австро-угорським ринками. Із суми депозиту український уряд міг оплачувати імпорт з Німеччини та Австро-Угорщини, проводити поточні виплати за своїми кредитними зобов'язаннями у цих країнах, а також використовувати 1 \% від загальної суми депозиту для розрахунків з третіми країнами [1, с. 37-38]. Через виснаженість війною німецького товарного ринку, а також заборону вивозу найбільш важливих фабрикатів, Україна не могла розраховувати на придбання потрібної їй продукції у великому обсязі, тоді як Центральні держави, закуповуючи продукти та сировину в Україні, могли швидко використовувати надану їм українську валюту [Там само, с. 38]. 3 огляду на реальну військовополітичну ситуацію в Україні на початку 1919 р. утрату урядом Директорії можливості здійснювати управління більшою частиною своєї території, а також через претензії радянського уряду на український депозит у Райхсбанку, Німеччина наклала ембарго на українські рахунки у своїх банках [Там само].

Працівники українського посольства, співробітники Міністерства закордонних справ УНР доклали багато зусиль задля того, щоб звільнити українські фінансові активи в німецьких банках і спрямувати ці кошти на міжнародну діяльність уряду та закупівлю необхідних товарів та озброєння. Уряд УНР ставив питання про видачу Німеччиною 400 мільйонів марок золотом. Німецька влада спочатку погоджувався з українськими претензіями. Однак незабаром із протестом проти претензій виступили радянські представники, які водночас висловили готовність виплатити німецьким кооперативним установам 50 мільйонів марок за доставлені в Україну товари [10, с. 38].

Однак поки йшло з'ясування долі коштів, покладених у німецькі банки урядом П. Скоропадського, у фінансових справах українських представництв у Німеччині виявилися зловживання з використанням коштів, отриманих з інших джерел. Щоб з'ясувати суть справи, до Берліна прибув голова торговельної комісії УНР за кордоном А. Сербиненко, який отримав повноваження, за участю ревізора військових місій отамана Олександра Жуковського, перебрати від посла М. Порша всі кредити, видані для закупівель військового майна та саме куплене для потреб української армії військове спорядження [26, с. 158]. Ревізія показала, що фінансове становище українського посольства катастрофрічне, каса порожня, а кошти передані посольству в розмірі 1 мільйона марок на видання преси, зникли [16, с. 143].

Проте найбільші зловживання ревізори виявили в роботі фінансового агента УНР у Німеччині Г. Супруна, на особистий рахунок якого було в Берліні покладено 8 мільйонів марок. Крім того, Г. Супрун оперував акредитивами на суму 150 млн марок [31, р. 306]. Виявлені 
недостачі фінансів спричинили в Берліні судовий процес між М. Васильком М. Поршом і Б. Мартосом та фінансовим агентом Г. Супруном [39, с. 276]. Урештірешт останній, запідозрений у розтратах через непідтверджені документи на 122 мільйони марок, утік до Нідерландів, а рахунки на його ім'я були арештовані [33, с. 117]. Такі зловживання й скандали негативно впливали на репутацію української дипломатії та уряду. Крім того, зазнали відчутних змін і моральна атмосфера серед працівників посольств та української еміграції [10, с. 291-292]. 3 іншого боку нестача коштів привела до скорочення персоналу українських інституцій у Німеччині та в інших країнах. У липні 1920 р. до Берліна прибув А. Ніковський з метою організації експозитури уряду МЗС і ліквідації різного роду дипломатичних місій $[46$, c. 5]

Питання українських активів у Німеччині остаточно вирішено за умовами Раппальського договору 16 квітня 1922 р., а також договору на поширення його дії на союзні з РСФРР радянські республіки, у т. ч. й Україну, в якому зафіксували взаємну відмову сторін від фінансових претензій [1, с. 39].

Наполегливість більшовиків у справі виконання умов Раппальського договору мали свої наслідки і в дипломатичній сорері. Навесні 1921 р. уряд Німеччини дозволив утворити при більшовицькому представництві у Берліні спеціальний відділ Радянської України для проведення репатріації українських військовополонених. Завідувачем українського відділу став Вольдемар Ауссем.

Внаслідок підписаної в Берліні угоди про розширення дії Раппальського договору на союзні з більшовицькою Росією республіки, зокрема, й на Україну, Німеччина встановила з останньою дипломатичні та консульські стосунки. Угода передбачала припинення Німеччиною будь-яких офріційних контактів з представниками української політичної еміграції. Спочатку нова позиція німецької влади торкнулася консульства УНР у Мюнхені. Там довгий час не було радянських представників. Однак ситуація докорінно змінилася після підписання Раппальського договору. У грудні 1922 р. з Берліна баварського уряду надійшов документ, у якому йшлося про визнання Німеччиною Радянської України, 3 того факту випливала втрата представництвами УНР урядового характеру. Тобто фактично, як зауважила В. Піскун, з грудня 1922 р. дипломатичні зносини на офріційному рівні між Німеччиною та УНР було припинено [10, с. 293-294]

Відповідно, було змушене припинити свою діяльність і посольство УНР. У березні 1923 р. співробітники українського посольства в Берліні покинули Німеччину [1, с. 41]. Р. Смаль-Стоцький у листі міністру закордонних справ Німеччини Розенбергу з цього приводу писав: "1) Відносини Німеччини до УНР почалися з того, що скоро після заключенню Брест-Литовського миру, 28 квітня 1918 р. німецький офріцер удерся в будинок Центральної Ради в Києві і зброєю розігнав перший український парламент. 2) Німецький уряд вмішався у війну українського народу проти московських большевиків, що тягнеться від 1919 р., тим, що захопив українське державне майно з метою знесилити і ослабити силу військового і економічного опору України і нарешті 11-го листопада 1922 р. поширив Раппальський Договір на Україну. 3) Відносини УНР до Німеччини були 6.II.1923 р. перервані в тій фрормі, що з наказу міністерства закордонних справ кримінальна поліція разом з українськими большевиками вдерлись в будинок Українського Посольства і примусили мене, представника Українського Уряду, звільнити його. Посольство законного Українського Уряду залишає Німецьку державу" [22, арк. 1]

\section{Висновки}

Таким чином, у 1918-1923 рр. кожний український революційний уряд (Центральної Ради, гетьмана Павла Скоропадського, Директорії УНР та ЗУНР) був представлений у Німеччині офріційно визнаними посольствами та консульськими установами. Діяльність українських дипломатичних структур у Німеччині, спрямована на визнання української незалежності, ускладнювалася ворожими діями більшовицької агентури, недостатньою фрінансовою підтримкою, внутрішніми проблемами персонального характеру. Окрім того, зовнішньополітичні можливості Німеччини були серйозно обмежені з боку країн Антанти. Проте українські дипломати в Берліні та Мюнхені чимало зробили в плані налагодження стосунків із німецькими політичними та економічними колами й дипломатами іноземних держав, акредитованих у Німеччині. Разом із Військово-санітарною місією та Місією українського Червоного Хреста посольства надавали допомогу полоненим-українцям, які утримувалися в таборах Німеччини, й сприяли тим, хто залишився в еміграції в цій країні й улаштувався працювати чи навчатися.

\section{ЛITЕРАТУРА}

1. Даниленко В. Передмова / В. Даниленко, Н. Кривець // Українські дипломатичні представництва в Німеччині (1918-1922): Документи і матеріали / [упор. В. М. Даниленко, Н. В. Кравець]. - К. : Смолоскип, 2012. - С. 5-45.

2. Матяш І. Головні події та знакові постаті інституційної історії української дипломатії 1917-1924 років / І. Матяш // Україна дипломатична. Науковий щорічник. - К., 2017. - С. 47-62.

3. Машевський О. Проблема визнання України державами Заходу та встановлення дипломатичних відносин у 19171919 рр. / О. Машевський // Україна дипломатична. Науковий щорічник. - К., 2017. - С. 81-90.

4. Головченко В. Поза межами можливого: Дипломатія УНР у боротьбі за незалежну національну державу / В. Головченко // Україна дипломатична. Науковий щорічник. - К., 2017. - C. $63-80$.

5. Дацків І. Підписання військової конвенції між Україною та Центральними Державами в Бресті 1918 р., її наслідки / І. Дацків // Україна дипломатична. Науковий щорічник. - К., 2017. - C. 101-111.

6. Дацків І. Б. Дипломатія Українських державних утворень у захисті національних інтересів 1917-1923 рp. / І. Дацків. - Тернопіль : Астон, 2009. - 520 с.

7. Гай-Нижник П. Україна-Грузія: становлення міждержавних і дипломатичних взаємин (1917-1921рр.) / П. Гай-Нижник // Україна дипломатична. Науковий щорічник. - К., 2017. C. $124-142$

8. Наріжний С. Українська еміґрація. Культурна праця української еміґрації 1919-1939 (матеріали, зібрані С. Наріжним до частини другої) / С. Наріжний. - К. : Вид-во ім. Олени Теліги, 1999. - 272 с.

9. Павлишин О. Євген Петрушевич (1863-1940). Ілюстрований біографічний нарис / О. Павлишин ; Інститут історичних досліджень Львівського національного університету імені Івана Франка; Програма дослідження модерної історії та суспільства України імені Петра Яцика. - Львів : МанускриптЛьвів, 2013. - 400 с.

10. Піскун В. Політичний вибір української еміграції (20-і роки XX століття) / В. Піскун. - К. : МП Леся, 2006. - 672 с.

11. Швагуляк М. Німеччина / М. Швагуляк // Світова історія: XX століття. Енциклопедичний словник / [за ред. І. Підкови та Р. Шуста]. - Львів : Літопис, 2008. - С. 562-571. 
12. Брицький П. П. Микола Василько - видатний український дипломат і політик / П. Брицький // Брицький П. Буковинці в боротьбі за українську державність (1917-1922 рр.) / П. Брицький, О. Добржанський, Є. Юрійчук. - Чернівці : Золоті литаври, 2007. - С. 55-153.

13. Брицький П. П. Микола Василько - видатний український дипломат і політик / П. Брицький, О. Добржанський // Брицький П. Буковинці в боротьбі за українську державність (19171922 рр.) / П. Брицький, О. Добржанський, Є. Юрійчук. - Чернівці : Золоті литаври, 2007. - С. 315-363.

14. Верстюк В. Діячі Української Центральної Ради. Бібліографічний довідник / В. Верстюк, Т. Осташко. - К., 1998. - 256 с.

15. Гай-Нижник П. Федір Штейнгель - меценат, громадсько-політичний діяч, посол Української Держави у Німеччині / П. Гай-Нижник // Дипломатична і консульська служба у вимірі особистості. - К., 2016 (Бібліотека наукового щорічника "Україна дипломатична", вип. № 13). - С. 95-124.

16. Гай-Нижник П. Микола Порш - державний і громадсько-політичний діяч, посол Української Народної Республіки в Німеччині / П. Гай-Нижник // Дипломатична і консульська служба у вимірі особистості. - К., 2016 (Бібліотека наукового щорічника "Україна дипломатична", вип. № 13). - С. 125-146.

17. Добржанський О. Микола Василько - визначний український дипломат австрійської школи / О. Добржанський // Дипломатична і консульська служба у вимірі особистості. К., 2016 (Бібліотека наукового щорічника "Україна дипломатична", вип. № 13). - С. 180-191.

18. Кедрин-Рудницький I. Роман Смаль-Стоцький як і політик і дипломат (Доповідь, виголошена 30 листопада 1963 р на Науковій конференції НТША в залі Українського інституту в Америці, в Нью-Йорку, у 70-ті роковини життя і 45-ті роковини громадської праці проф. Романа Смаль-Стоцького) / І. Кедрин-Рудницький // Записки Наукового товариства ім. Шевченка. T. CLXXVII: На пошану сімдесятиріччя народин Романа Смаль-Стоцького / [редактори: Василь Лев і Матвій Стахів]. Нью-Йорк-Париж-Сідней-Торонто, 1963. - С. 24-32.

19. Кривець Н. В. Штейнгель Федір Рудольфович / Н. В. Кривець // Україна в міжнародних відносинах. Енциклопедичний словник-довідник / Національна академія наук України. Інститут історії України. - К., 2016. - Вип. 6. Біографрічна частина: НЯ. - С. 333-334.

20. Матяш І. Б. Оренчук Василь Якович / І. Б. Матяш // Україна в міжнародних відносинах. Енциклопедичний словник-довідник / Національна академія наук України. Інститут історії України. - К., 2016. - Вип. 6. Біографічна частина: Н-Я. C. $57-59$.

21. Матяш І. Останній консул УНР Василь Оренчук / І. Матяш // Дипломатична і консульська служба у вимірі особистості. - К., 2016 (Бібліотека наукового щорічника "Україна дипломатична", вип. № 13). - С. 352-369.

22. Центральний державний історичний архів України у Львові, ф. 581 (Колекція документів про діяльність урядів та армії УНР і ЗУНР), оп 1, спр. 24 (Лист посла УНР в Берліні Смаль-Стоцького Р. до міністра закордонних справ Розенберга про причини свого від'їзду з Німеччини), 1 арк. (1923р.)

23. Архів Української Народної Республіки. Міністерство закордонних справ. Дипломатичні документи від Версальського до Ризького мирних договорів (1919-1921) / [упор. Валентин Кавунник]. - К. : Інститут української археографії та джерелознавства ім. М. С. Грушевського, 2016. - 796 с.

24. Західно-Українська Народна Республіка 1918-1923. Документи і матеріали у 5-ти томах / [керівник роботи і відповідальний редактор Олександр Карпенко]. - Івано-Франківськ : Лілея-НВ, 2001. - Т. 2. - 712 с.

25. Симон Петлюра. Статті. Листи. Документи / Українська Вільна Академія Наук у США; Бібліотека ім. Симона Петлюри в Парижі. - Нью-Йорк, 1979. - Т. II. - 627 с.

26. Симон Петлюра. Статті, листи, документи. - Т. III / [упорядник В. Сергійчук]. - К. : Вид-во ім. Олени Теліги, 1999. - 616 c.

27. Українська політична еміграція 1919-1945: Документи і матеріали. - К. : Парламентське вид-во, 2008. - 928 с. + 16 с. іл.
28. Українські дипломатичні представництва в Німеччині (1918-1922): Документи і матеріали / [упор. В. М. Даниленко, Н. В. Кравець]. - К. : Смолоскип, 2012. - 592 с.: іл.

29. Українські представництва, місії та інституції за кордоном // Воля. - Відень, 1919. - 19 липня. - Ч. 3. - С. 47-48.

30. The Ukranian Revolution documents 1919-1921 / [Taras Hunczak, ed.]. - New York, 1984. - Vol. 2. - 478 p.

31. Ukraine and Poland in documents 1918-1922. Part I / Shevchenko Scientific Society ; [edited by Taras Hunczak]. - New York-Paris-Sydney-Toronto, 1983 (= Sourses for the History of Ruś-Ukraine. - Vol. XII). - 456 p.

32. Ukraine and Poland in documents 1918-1922. Part II / Shevchenko Scientific Society ; [edited by Taras Hunczak]. - New York-Paris-Sydney-Toronto, 1983 (= Sourses for the History of Ruś-Ukraine. - Vol. XII). - 468 p.

33. Онацький $€$. По похилій площині. Записки журналіста i дипломата / Є. Онацький. - Мюнхен : Дніпрова Хвиля, [б. д.]. 4. II. $-262 \mathrm{c}$.

34. Записна книжка О. Жуковського з 1919 року // Український історик. - Нью-Йорк; Торонто; Мюнхен, 1986. - Ч. 1-2. С. $75-86$.

35. Пропам'ятна книга Данцінґерів. Історичні нариси та спомини колишніх студентів Політехніки Вільного Міста Данцінґу 1921-1945. Матеріали вибрав і приготовив до друку Володимир Шиприкевич / Накладом Архівної Комісії Данцінґерів. - Філядельфія; Торонто; Нью-Йорк, 1979. - 218 с.

36. Воля. - Відень, 1919. - 30 серпня. - Ч. 5. - С. 234.

37. Воля. - Відень, 1920. - 10 січня. - Ч. 2. - С. 87-89.

38. Воля. - Відень, 1920. - 14 лютого. - Ч. 7. - С. 331-332.

39. Воля. - Відень, 1920. - 29 травня. - Ч. 6. С. 274-277.

40. Воля. - Відень, 1920. - 20 листопада. - Ч. 7/8. - С. 409410.

41. Воля. - Відень, 1920. - 10 липня. - Ч. 2. - С. 80

42. Воля. - Відень, 1921. - 15 січня. - Ч. 3. - С. 153-157.

43. Воля. - Відень, 1921. - 5 лютого. - Ч. 6. - С. 300-301.

44. Воля. - Відень, 1921. - 3 липня. - Ч. 1/2. - С. 70-72.

45. Український Прапор. - Відень, 1920. - 6 червня. - С. 3. 46. Український Прапор. - Відень, 1920. - 11 липня. - С. 5.

47. Заболотнюк В. Українська військово-санітарна місія для справ полонених у Німеччині (1918-1920) / В. Заболотнюк // Військово-науковий вісник. - Випуск 28. - Львів : НАСВ, 2017. - C. 21-33.

48. Миронець Н. Р. Книжково-рукописне зібрання барона Ф. Р. Штейнгеля: формування, зміст, доля : автореф. дис. на здобуття наук. ступеня канд. іст. наук : спец. 07.00.08 / Миронець Ніна Ростиславівна ; НАН України, Національна бібліотека України ім. В. І. Вернадського. - К., 2004. - 18 с.

49. Воронкова Т. І. Штейнгель Федір Рудольфович / Т. І. Воронкова // Особові архівні Фонди Інституту рукопису: Путівник ; Нац. б-ка України ім В. І. Вернадського. - К., 2003. - С. 602605 .

50. Caroline Milow. Die ukrainische Frage 1917-1923 im Spannungsfeld der europäischen Diplomatie. Diss. Harrassowitz Verlag / Caroline Milow. - Wiesbaden, 2002. - 570 Seiten.

51. Borowsky P. Deutsche Ukrainepolitik 1918 unter besonderer Brücksichtigung der Wirtschaftsfragen / P. Borowsky. - Lübeck, 1970.

52. Fedenko P. Der nazionale und soziale Befraiungskampf der Ukraine / P. Fedenko. - Berlin, 1923.

53. Heyer F. Die orthodoxe Kirche in der Ukraine von 1917 bis 1945 / F. Heyer. - München, 1953.

54. Kerstin S. Jobst: Geschichte der Ukraine [Електронний pecypc] / S. Kerstin. - Stuttgart : Reclam, 2010. - Режим доступу : https://www.amazon.de/Geschichte-Ukraine-ReclamsUniversal-Bibliothek-Kerstin/dp/3150193206

55. Frank Grelka. Die ukrainische Nationalbewegung unter deutscher Besatzungsherrschaft 1918 und 1941/42. Harrassowitz Verlag [Електронний ресурс] / Frank Grelka. - Wiesbaden, 2006. - 507 Seiten. - Режим доступу : https://www.perlentaucher.de/ buch/frank-grelka/die-ukrainische-nationalbewegung-unterdeutscher-besatzungsherrschaft-1918-und-1941-42.html 
Заболотнюк Владимир,

соискатель, ведущий научный сотрудник

Научно-исследовательского отдела (механизированных и танковых войск),

Научный центр Национальной академии сухопутных войск, г. Львов

\section{УКРАИНСКИЕ ДИПЛОМАТИЧЕСКИЕ ИНСТИТУЦИИ В ГЕРМАНИИ В 1918-1923 22.}

В статье рассматривается становление и деятельность в Германии украинских посольств и консульских учреждений в 1918-1923 гг. В Берлине были представлены дипломатические учреждения Украинской Народной Республики периода Центральной Рады (посол Александр Севрюк), Украинской Державы (барон Федор Штейнгель), Украинской Народной Республики времен Директории УНР (Николай Порш, Роман Смаль-Стоцкий). Свое посольство образовала в Берлине и Западно-Украинская Народная Республика (Евгений Левицкий, Ярослав Биберович). Но, учитывая возможную негативную реакцию стран Антанты, посольство ЗУНР не развило более широкую деятельность. Украина имела свои консульские учреждения в Берлине и Мюнхене. В статье упоминается также о деятельности украинского консульского учреждения в Данциге (Гданьске), который был тесно связан с Германией. Украинские дипломатические структуры в Германии были официально признаны немецкой властью и свои главные усилия направили на поиски внешней поддержки Украины в борьбе с врагами ее независимости. Дипломаты вместе с военно-санитарными миссиями осуществляли опеку над пленными украинцами - воинами бывшей российской армии, которые содержались в лагерях Германии, а также заботились о тех украинцах, которые остались в эмиграции и работали или учились в этой стране.

Ключевые слова: дипломатия; посольства; консульськие учреждения; военная эмиграция; Ярослав Биберович; Евгений Левицкий; Николай Порш; Олександр Севрюк; Роман Смаль-Стоцкий; Федор Штейнгель.

Zabolotniuk Volodymyr,

Applicant, Senior Researcher of the Research Department (mechanized and armored troops),

Science Center of the of the National Army Academy

\section{UKRAINIAN DIPLOMATIC MISSION IN GERMANY IN 1918-1923}

The article considers with the formation and activities in Germany of Ukrainian embassies and consular offices in 1918-1923. Diplomatic institutions were represented in Berlin: the Ukrainian People's Republic of the Central Rada (Ambassador Alexander Sevryuk), the Ukrainian State (baron Fedor Shteyngel), the Ukrainian People's Republic Directory of the UNR (Mykola Porch, Roman Smal-Stotsky). His embassy was formed in Berlin and the Western Ukrainian National Republic (Yevhen Levytsky, Yaroslav Byberovych). But in view of the possible negative reaction of the Entente countries, the ZUNR (WUNR) embassy did not develop widly. Ukraine had its consular offices in Berlin and Munich. The article also mentions the activities of the Ukrainian consular establishment in Danzing (Gdansk), which was closely linked with Germany. The Ukrainian diplomatic structures in Germany were officially recognized by the German authorities and focused their efforts on seeking external support from Ukraine in the struggle against the enemies of its independence.

The informational office of the embassy in Berlin tried to get the German press and the general public informed about the Ukrainian issue as much as possible and gathered the necessary information for the Ukrainian government. The Ukrainian embassy in Germany solved the actual foreign policy tasks not only in relations with the host country. Diplomats have imposed international contacts with embassies of other countries accredited in the capital of Germany. The activity of the Ukrainian diplomatic structures was aggravated by the hostile actions of the Bolshevik agents, insufficient financial support, and internal problems of a personal nature. In addition, the foreign policy capabilities of Germany were severely restricted by the Entente countries.

The diplomats, together with the military-medical missions, took care of the captive Ukrainians - the soldiers of the former Russian army who were held in the German camps, and also cared for by those Ukrainians who remained in exile and worked or studied in this country.

Key words: diplomacy; embassy; consular offices; military emigration; Yaroslav Biberovich; Even Levitskiy; Mikola Porsh; Olexander Sevryuk; Roman Smal-Stotsky; Fedir Shteingel.

\section{REFERENCES}

1. Danilenko, V. and Kravets, N. (2012). Preface : Ukrainian diplomatic representations in Germany (1918-1922): Documents and materials Smoloskyp, Kyiv: 5-45 (ukr).

2. Matiash, I. (2017). Main Events and Signs of the Institutional History of Ukrainian Diplomacy, 917-1924. Ukraine Diplomatic. Scientific Yearbook. Kyiv: P. 47-62 (ukr).

3. Mashevsky, Oleg (2017). The problem of recognition of Ukraine by the states of the West and the establishment of diplomatic relations in 1917-1919. Ukraine diplomatic. Scientific Yearbook. Kyiv: 81-90 (ukr).

4. Golovchenko, Volodymyr (2017). Outside the possible: UNR in the struggle for an independent national state. Ukraine diplomatic. Scientific Yearbook. Kyiv: 63-80 (ukr).

5. Datskiv, Igor (2017). Signing of the military convention between Ukraine and the Central Powers in Brest in 1918, its consequences. Diplomatic Ukraine. Scientific Yearbook. Kyiv: 101-111 (ukr).

СХІД № 6 (152) листопад-грудень 2017 р. 
6. Datskiv, Igor (2009). Diplomacy of Ukrainian State Institutions for the Protection of National Interests of 1917-1923. Aston, Ternopil: 520 p. (ukr).

7. Guy-Nizhnik, Pavel (2017). Ukraine-Georgia: Establishment of Interstate and Diplomatic Relations (1917-1921). Diplomatic Ukraine. Scientific Yearbook. Kyiv: 124-142.

8. Narizhny, Simon (1999). Ukrainian emigration. Cultural Work of Ukrainian Immigration 1919-1939 (Materials collected by S. Narodny to the second part). Publishing House named after Olena Teligi, Kyiv. 272 p. (ukr).

9. Pavlyshyn, Oleg (2013). Yevgeny Petrushevich (1863-1940). Illustrated biographical sketch. Manuscript-Lviv, Lviv: 400 p. (ukr). (ukr).

10. Piskun, Valentyna (2006). Political choice of Ukrainian emigration (20 years of the twentieth century) «MP Lesya», Kyiv: 672 pp.

11. Shvagulyak, Mykhaylo (2008). Germany In: World History: XX Century. Encyclopedic Dictionary. Litopys Publishing, Lviv: 562571 pp. (ukr).

12. Brytsky, P.P. \& Dobrzhansky, O.V. \& Yuryychuk, E. (2007). Nikolay Vasilko - prominent Ukrainian diplomat and politician. In: Bukovintsi in the struggle for Ukrainian statehood (1917-1922). Gold Lithavers, Chernivtsi: 55-153 pp. (ukr).

13. Brytsky, P.P. \& Dobrzhansky, O.V. \& Yuryychuk, E. (2007). Roman Smal-Stotsky - diplomatic, socio-political, scientific and pedagogical activity. In: Bukovintsi in the struggle for Ukrainian statehood (1917-1922). Gold Lithavers, Chernivtsi: 315-363 pp. (ukr). (ukr).

14. Verstyuk, V. and Ostashko, T. (1998), The characters of the Ukrainian Central Rada. Bibliographic guide. W.p., Kyiv: 256 pp.

15. Guy-Nyzhnyk, Pavlo (2016). Feodor Shteynhel - philanthropist, public figure, Ambassador of the Ukrainian State in Germany. In: Diplomatic and consular service in the dimension of personality. Kyiv: 95-124 pp. (ukr).

16. Guy-Nyzhnyk, Pavlo (2016). Mykola Porsh - public and political figure, Ambassador of the Ukrainian People's Republic in Germany. In: Diplomatic and consular service in the dimension of personality. Kyiv: 125-146 pp. (ukr).

17. Dobrzhansky, Olexander (2016). Nikolay Vasilko - prominent Ukrainian diplomat of the Austrian school In: Diplomatic and consular service in the dimension of personality. Kyiv: 180-191 pp. (ukr).

18. Kedrin-Rudnytsky, Ivan \& Lev, Vasily [ed.] and Stakhov, Matthew [ed.] (1963). Roman Smal-Stotsky as a politician and diplomat. Notes of the Scientific Society to them. Shevchenko T. CLXXVII: In honor of the seventieth anniversary of the people of Roman SmalStotsky. New York-Paris-Sydney-Toronto: 24-32 pp (ukr)

19. Kryvets, N.V. (2016). Steingel Fedir Rudolfovych. In: Ukraine in international relations. Encyclopedic Dictionary-Directory Issue 6. Biographical part: "N-Ya". National Academy of Sciences of Ukraine. Institute of History of Ukraine. Kyiv, 2016: 333-334 pp. (ukr).

20. Matyas, I. B. (2016). Orenchuk Vasyl Yakovych In: Ukraine in international relations. Encyclopedic Dictionary-Directory Issue 6. Biographical part: "N-Ya". National Academy of Sciences of Ukraine. Institute of History of Ukraine. Kyiv, 2016: 57-59 pp. (ukr).

21. Matyas, I. B. (2016). The last consul of the UPR, Vasily Orenchuk In: Diplomatic and consular service in the dimension of personality. Kyiv: 352-369 pp. (ukr).

22. Central State Historical Archive of Ukraine in Lviv, fond 581 (Collection of documents on the activities of the Government and Army of the UNR and ZUNR), opys 1, sprava 24 (Letter from the Ambassador of the UNR in Berlin to the Speaker of the Smal-Stotsky to the Minister for Foreign Affairs of Rosenberg on the reasons for his departure from Germany), 1 ark. (1923)

23. Kavunnyk, Valentyn (2016). Archive of the Ukrainian People's Republic. Ministry of International Affairs. Diplomatic documents from Versailles to Riga Peace treaties (1919-1921). Institute of Ukrainian Archeography and Source Studies named after. MS Hrushevsky, Kyiv: 796 pp. (ukr).

24. Karpenko, Oleksandr [ed.] (2001). Western Ukrainian People's Republic 1918-1923. Documents and materials in 5 volumes. Vol.

2. Lileia-HB, Ivano-Frankivsk: 712 p. (ukr).

25. Ukrainian Free Academy of Sciences in the USA; Library of them Simon Petliura in Paris (1979). Simon Petliura. Articles. Letters Documents. Vol.2: New York: 627 pp. (ukr).

26. Serhiychuk, Volodymyr [ed., compil.] (1999). Simon Petliura. Articles, letters, documents. Vol. III. Publishing house named after Olena Teliga, Kyiv, 616 p. (ukr).

27. Ukrainian Political Emigration 1919-1945: Documents and Materials (2008). Parliamentary Publishing, Kyiv: 928 pp. (ukr).

28. Danylenko, V. M. [compil.] and Kravets, N. V. [compil.] (2012). Ukrainian diplomatic missions in Germany (1918-1922): Documents and materials. Smoloskyp, Kyiv: 592 p. (ukr).

29. Volia (1919). Ukrainian Representations, Missions and Institutions Abroad. Vienna, 19th of July. Part. 3: 47-48 (ukr).

30. Hunczak, Taras [ed.] (1984). The Ukranian Revolution documents 1919-1921. Part. 2. New York: 478 p. (eng).

31. Hunczak, Taras [ed.] (1983). Ukraine and Poland in documents 1918-1922. Part I. Shevchenko Scientific Society. New York-

Paris-Sydney-Toronto, $456 \mathrm{p}$. (eng).

32. Hunczak, Taras [ed.] (1983). Ukraine and Poland in documents 1918-1922. Part II. Shevchenko Scientific Society. New York-

Paris-Sydney-Toronto, 468 p. (eng).

33. Onatsky, Yevgen (No Date). On a sloping plane. Notes from journalist and diplomat: Ch. II. Dnieper Wave, Munich: 262 p. (ukr).

34. Ukrainian historian (1986). A notebook of O. Zhukovsky from 1919. Ch. 1-2. New York; Toronto; Munich: 75-86 pp. (ukr).

35. Shyrrekevych, Volodymyr [compil.] (1979). Danzinger's Memorable Book. Historical Essays and Remembrances of the Former

Students of the Free University of Danzing, 1921-1945. Philadelphia; Toronto; New York: 218 p. (ukr).

36. Volia (1919). Vienna, 30 August. Part. 5: 234 pp. (ukr).

37. Volia (1920). Vienna, 10 January. Part. 2: 89-89 pp. (ukr).

38. Volia (1920). Vienna, 14 February. Part. 7: 331-332 pp. (ukr).

39. Volia (1920). Vienna, 29 May. Part. 6: 274-277 pp. (ukr).

40. Volia (1920). Vienna, 20 November. Part. 7/8: 409-410 pp. (ukr).

41. Volia (1920). Vienna, 10 July. Part. 2: 80 pp. (ukr).

42. Volia (1921). Vienna, 15 January. Part. 3: 153-157 pp. (ukr).

43. Volia (1921). Vienna, 5 February. Part. 6: 300-301 pp. (ukr).

44. Volia (1921). Vienna, 3 July. Part. 1/2: 70-72 pp. (ukr).

45. Ukrayinskyy Prapor (1920). Vienna, 6 June: 3 pp. (ukr).

46. Ukrayinskyy Prapor (1920). Vienna, 11 July: 5 pp. (ukr). 
47. Zabolotniuk, V. (2017). Ukrainian Military-Sanitary Mission for the Affairs of the Captives in Germany (1918-1920). Military Scientific Bulletin. Issue 28. Lviv (NASA): 21-33 (ukr).

48. Myronets, Nina (2004). Book-handwriting collection of Baron F. R. Shteynhel: formation, content, fate Abstract of thesis for the degree of candidate of historical sciences in specialty: 07.00.08. National Academy of Sciences of Ukraine, Kyiv, $18 \mathrm{p}$.

49. Voronkova, T. I. (2003). Steingel Fedir Rudolfovych In: Personal archival funds of the Institute of Manuscripts: Guide National. b-ka Ukraine them. VI VernadskyKyiv: 602-605 pp.

50. Milow, Caroline (2002). The Ukrainian question 1917-1923 in the field of tension of European diplomacy. Diss. Harrassowitz Verlag, Wiesbaden Broschiert, 570 p. (germ).

51. Borowsky, P. (1970). German Ukraine Politics 1918 with special attention to economic issues. Lubeck (germ).

52. Fedenko, P. (1923). The Nazi and social Befraiungskampf of Ukraine. Berlin (germ).

53. Heyer, F. (1953). The Orthodox Church in Ukraine from 1917 to 1945. Munich (germ).

54. Kerstin, S. (2010). Jobst: Geschichte der Ukraine, Stuttgart, available at: https://www.amazon.de/Geschichte-Ukraine-ReclamsUniversal-Bibliothek-Kerstin/dp/3150193206 (germ).

55. Frank, Grelka (2006). Die ukrainische Nationalbewegung unter deutscher Besatzungsherrschaft 1918 und 1941/42. Harrassowitz Verlag, Wiesbaden, 507 p., available at: https://www.perlentaucher.de/buch/frank-grelka/die-ukrainische-nationalbewegung-unterdeutscher-besatzungsherrschaft-1918-und-1941-42.html (germ).

() Заболотнюк Володимир

Надійшла до редакції 06.12.2017

УДК 351.746.1(477)(092)"1945"

DOI: $10.21847 / 1728-9343.2017 .6(152) .122346$

\title{
ЛЕВИК БОГДАН,
}

доктор історичних наук, доцент кафедри історії, музеєзнавства та культури,

Національний університет "Львівська політехніка"

\section{ВОЛОДИМИР БУЖИНСЬКИЙ, НАУКОВЕЦЬ ЛЬВІВСЬКОї ПОЛІТЕХНІКИ, у матеріалах НКДБ за січень-липень 1945 р.}

\begin{abstract}
Стаття продовжує серію публікацій про вчених Львівської політехніки, репресованих радянською владою за надуманими звинуваченнями в 1944-1945 роках. Розглянуто перебіг слідчої справи № 1271 (архівний номер П-2284) Бужинського Володимира Мар'яновича, доктора технічних наук, завідувача кафедри опору матеріалів та гідромеханіки Львівського політехнічного інституту. Поряд 3 аналізом документів слідчої справи наведені маловідомі й невідомі факти 3 життя професора, його ставлення до роботи у вищому навчальному закладі та мотиви, якими він керувався, працюючи у виші за німецької окупації. Показано, що скасування звинувачень щодо вченого пов'язано не стільки з доведенням його невинуватості, скільки зі зміною політики радянської влади щодо поляків, яких вона примусила покидати Львів за програмою репатріації на підставі "Угоди про взаємний обмін населенням у прикордонних районах" 1944 року.
\end{abstract}

Ключові слова: Львівський політехнічний інститут; репресовані вчені; Бужинський Володимир Мар'янович.

Постановка проблеми. Наприкінці Другої світової війни, коли поразка гітлерівської Німеччини вже була очевидною, перед країнами антигітлерівської коаліції СРСР, Великобританією та США - постало питання про поділ зон впливу на звільнених від німецької окупації землях Європи.

Доля Львова і Галичини викликала особливі дискусії серед представників основних політичних гравців світу. Попри спротив більшості польських лідерів громадської думки того часу [1] та за мовчазної згоди Великобританії, яка надала Польщі гарантії недоторкан- ності ще 31 березня 1939 року, Львів залишився у складі СРСР (до якого він увійшов у 1939 році згідно з пактом Молотова-Ріббентропа), упродовж 1946 року його покинула більшість поляків, що населяли це місто.

Але до того, як офріційне рішення про обмін населенням ${ }^{1}$ набрало сили на місцях, а міські жителі усвідомили всі небезпеки й загрози від нового радянсько-

\footnotetext{
1 Мається на увазі "Угода про взаємний обмін населенням у прикордонних районах", підписана в 1944 році між урядами УРСР і Польської Республіки (прим. ред.)
} 